\title{
KECERDASAN EMOSI SISWA PADA PENINGKATAN HASIL BELAJAR IPS MELALUI BELAJAR KOOPERATIF DI SD LABORATORIUM UNG
}

\author{
EImia Umar \\ Universitas Islam Negeri Gorontalo, Jl. Jendral Soedirman no. 06 \\ email: infoelmiaumar@gmail.com
}

\begin{abstract}
The objective of this research is to know the learning process to increase elementary student outcomes in social science study through the cooperative learning and whether there was an increase after the action. About 20 students of School Laboratories, State University of Gorontalo were the subject of research. The research used action research method with data collecting technique including field notes, interview, documentation and observation. The result of the research describes that the cooperative learning in social science study gives impact for increasing social science learning of elementary school proved by increasing of score test average by $85 \%$ and the result in observation showed by $80 \%$ from the total number of student.
\end{abstract}

Keywords: learning process, cooperative learning, action research

\begin{abstract}
Abstrak
Penelitian ini bertujuan untuk mengetahui proses pembelajaran mata pelajaran IPS siswa Sekolah Dasar melalui pembelajaran kooperatif dan melihat apakah terdapat peningkatan hasil belajar. 20 orang siswa SD Laboratorium Universitas Negeri Gorontalo menjadi subyek penelitian. Metode penelitian yang digunakan adalah penelitian tindakan dengan teknik pengumpulan data melalui catatan lapangan, wawancara,dokumentasi dan observasi.Hasil dari penelitian menggambarkan bahwa pembelajaran kooperatif dalam pelajaran IPS memberikan dampak dalam pembelajaran IPS siswa SD dengan peningkatan skor tes rata-rata $85 \%$ dan hasil observasi menunjukkan peningkatan oleh $80 \%$ dari total siswa.
\end{abstract}

Kata kunci: proses pembelajaran, pembelajaran kooperatif, penelitian tindakan

\section{PENDAHULUAN}

Secara umum keberhasilan proses pembelajaran di sekolah dasar sangat ditentukan oleh beberapa komponen yaitu baik yang berasal dari guru, peserta didik, sarana dan prasarana dan kurikulum. Komponen-komponen ini akan saling berkaitan antara yang satu dengan yang lain.Guru tanpa peserta didik tidak akan terjadi proses pembelajaran, demikian juga peserta didik tanpa komponen yang lain tidak mungkin terjadi proses pembelajaran.

Mata pelajaran Ilmu Pengetahuan Sosial merupakan mata pelajaran yang wajib diajarkan secara formal dari kelas I sampai kelas VI SD. Mata pelajaran Ilmu Pengetahuan Sosial pada jenjang SD dewasa ini dihadapkan pada tantangan untuk mempersiapkan peserta didik agar menjadi warga negara indonesia yang demokratis dan bertanggung jawab serta warga dunia yang cinta damai, sebagaimana yang tertuang dalam kurikulum pendidikan dasar bahwa mata pelajaran IPS bertujuan agar peserta didik memiliki kemampuan sebagai berikut: (1). Mengenal konsep-konsep yang berkaitan dengan kehidupan masyarakat dan lingkungannya, (2). Memiliki kemampuan dasar untuk berpikir logis dan kritis, rasa ingin tahu, inkuiri, memecahkan masalah dan keterampilan dalam kehidupan sosial, (3). Memiliki komitmen dan kesadaran terhadap nilai-nilai sosial dan kemanusiaan, (4). Memiliki kemampuan berkomunikasi, bekerjasama dan berkompetisi 
dalam masyarakat yang majemuk ditingkat lokal, nasional dan global. ${ }^{1}$

Untuk mendapatkan kemampuan yang dituntut seperti dijelaskan diatas maka siswa perlu difasilitasi agar mampu mengembangkan pengetahuan, kecakapan atau keterampilan, sikap, nilai dan komitmen yang dibutuhkan serta kemampuan mengakui kemajemukan dalam masyarakat.

Berdasarkan pengamatan peneliti di lapangan saat ini pembelajaran IPS di SD Laboratorium UNG terlihat pembelajarannya masih bersifat konvensional yaitu guru yang masih mendominasi dalam proses pembelajaran. Pola pembelajaran yang diterapkan oleh guru pada setiap perte-muan adalah menjelaskan materi pelajaran, memberikan contoh-contoh, memberikan latihan dan diakhir pelajaran memberikan pekerjaan rumah ( PR ).

Perhatian guru dalam pola pembelajaran konvensional lebih banyak tercurah pada ketuntasan penyampaian materi, motivasi atau dorongan untuk belajar aktif melalui bimbingan dan mengajar dari guru belum terlihat, komunikasi dalam pembelajaran hanya satu arah yaitu hanya bersumber pada guru, akibatnya sebagian besar siswa bersikap pasif dalam mengikuti pembelajaran. Guru belum merancang perangkat pembelajaran yang mampu mengakomodasi kebutuhan siswa untuk belajar lebih aktif serta model pembelajaran yang digunakan masih kurang bervariasi, tidak adanya interaksi antar siswa sehingga hal ini berakibat pada rendahnya hasil capaian belajar IPS di sekolah dasar laboratorium Universitas Negeri Gorontalo.

Upaya peningkatan hasil belajar siswa tidak terlepas dari berbagai faktor yang mempengaruhinya. Dalam hal ini diperlukan guru kreatif yang dapat membuat pembelajaran menjadi lebih menarik dan disukai oleh peserta didik. Suasana kelas perlu direncanakan dan dibangun

\footnotetext{
${ }^{1}$ Depdiknas, Kurikulum Pendidikan Dasar Tahun 2006, h,621.
}

sedemikian rupa dengan menggunakan model pembelajaran yang tepat agar siswa dapat memperoleh kesempatan untuk berinteraksi satu sama lain sehingga pada gilirannya dapat diperoleh hasil belajar yang optimal.

Pembelajaran kooperatif dapat mem-belajarkan diri dan kehidupan siswa sekaligus memberikan pelatihan hidup senyatanya. Belajar kooperatif atau cooperatif learning dapat dirumuskan sebagai kegiatan pembelajaran kelompok yang terarah, terpadu, efektif, efisien kearah mencari atau mengkaji sesuatu melalui proses kerja sama dan saling membantu (sharing), sehingga tercapai proses dan hasil belajar yang produktif.

Anak bukan saja diajarkan berbagai pengetahuan saja, tetapi juga diajarkan suatu keterampilan tertentu. Pengetahuan dan keterampilan perlu diberikan dan dipersiapkan untuk mengantisipasi berbagai masalah kehidupan yang dihadapi siswa.

Upaya belajar adalah segala aktivitas siswa untuk meningkatkan kemampuan baru, baik kemampuan dalam aspek pengetahuan, sikap maupun ketrampilan. Aktivitas pembelajaran tersebut dilakukan dalam kegiatan kelompok, sehingga antar peserta dapat saling membelajarkan melalui tukar pikiran, pengalaman maupun gagasangagasan.

Salah satu strategi model pembelajaran kelompok adalah pembelajaran kooperatif (Cooperative Learning). Pembelajaran kooperatif menekankan kerjasama antar siswa dalam kelompok. Hal ini dilandasi oleh pemikiran bahwa siswa lebih mudah menemukan dan memahami suatu konsep jika mereka saling mendiskusikan masalah tersebut dengan temannya.

Dari uraian di atas, peneliti yakin, dengan menerapkan belajar kooperatif pembelajaran akan terasa lebih bermakna dan bervariasi sehingga nantinya diharapkan dapat lebih membangkitkan semangat dan aktivitas siswa dalam belajar yang menimbulkan kekuatan kemauan bereaksi, 
apabila dipancing oleh adanya usaha memenuhi kebutuhan maka kemauan beraktualisasi diri sebagai kekuatan mendorong perbuatan mencapai tujuan belajar yang diharapkan berupa peningkatan hasil belajar IPS di SD Laboratorium UNG.

\section{KAJIAN TEORETIK DAN HIPOTE- SIS TINDAKAN}

\section{A. KAJIAN TEORETIK \\ 1. Kecerdasan Emosi}

Salovey dan Mayer mendefinisikan kecerdasan emosional atau yang sering disebut EQ sebagai: "himpunan bagian dari kecerdasan sosial yang melibatkan kemampuan memantau perasaan sosial yang melibatkan kemampuan pada orang lain, memilah-milah semuanya dan menggunakan informasi ini untuk membimbing pikiran dan tindakan." (Shapiro, 1998:8).

Kecerdasan emosional sangat dipengaruhi oleh lingkungan, tidak bersifat menetap, dapat berubah-ubah setiap saat. Untuk itu peranan lingkungan terutama orang tua pada masa kanak-kanak sangat mempengaruhi dalam pembentukan kecerdasan emosional.

Keterampilan EQ bukanlah lawan keterampilan IQ atau keterampilan kognitif, namun keduanya berinteraksi secara dina-mis, baik pada tingkatan konseptual maupun di dunia nyata. Selain itu, EQ tidak begitu dipengaruhi oleh faktor keturunan. (Shapiro, 1998-10). Sebuah model pelopor lain yentang kecerdasan emosional diajukan oleh Bar-On pada tahun 1992 seorang ahli psikologi Israel, yang mendefinisikan kecerdasan emosional sebagai serangkaian kemam-puan pribadi, emosi dan sosial yang mempengaruhi kemampuan seseorang untuk berhasil dalam mengatasi tututan dan tekanan lingkungan (Goleman, $2000: 180$ ).

Gardner dalam bukunya yang berjudul Frame Of Mind (Goleman, 2000: 50-53) mengatakan bahwa bukan hanya satu jenis kecerdasan yang monolitik yang penting untuk meraih sukses dalam kehidupan, melainkan ada spektrum kecer- dasan yang lebar dengan tujuh varietas utama yaitu linguistik, matematika/logika, spasial, kinestetik, musik, interpersonal dan intrapersonal. Kecerdasan ini dinamakan oleh Gardner sebagai kecerdasan pribadi yang oleh Daniel Goleman disebut sebagai kecerdasan emosional.

Menurut Gardner, kecerdasan pribadi terdiri dari :"kecerdasan antar pribadi yaitu kemampuan untuk memahami orang lain, apa yang memotivasi mereka, bagaimana mereka bekerja, bagaimana bekerja bahu membahu dengan kecerdasan. Sedangkan kecerdasan intra pribadi adalah kemampuan yang korelatif, tetapi terarah ke dalam diri. Kemampuan tersebut adalah kemampuan membentuk suatu model diri sendiri yang teliti dan mengacu pada diri serta kemampuan untuk menggunakan modal tadi sebagai alat untuk menempuh kehidupan secara efektif." (Goleman, 2002 : 52).

Dalam rumusan lain, Gardner menyatakan bahwa inti kecerdasan antar pribadi itu mencakup "kemampuan untuk membedakan dan menanggapi dengan tepat suasana hati, temperamen, motivasi dan hasrat orang lain." Dalam kecerdasan antar pribadi yang merupakan kunci menuju pengetahuan diri, ia mencantumkan "akses menuju perasaan-perasaan diri seseorang dan kemampuan untuk membedakan perasaan-perasaan tersebut serta memanfaatkannya untuk menuntun tingkah laku". (Goleman, 2002 : 53).

Berdasarkan kecerdasan yang dinyatakan oleh Gardner tersebut, Salovey (Goleman, 200:57) memilih kecerdasan interpersonal dan kecerdasan intrapersonal untuk dijadikan sebagai dasar untuk mengungkap kecerdasan emosional pada diri individu. Menurutnya kecerdasan emosional adalah kemampuan seseorang untuk mengenali emosi diri, mengelola emosi, memotivasi diri sendiri, mengenali emosi orang lain (empati) dan kemampuan untuk membina hubungan (kerjasama) dengan orang lain.

Menurut Goleman (2002:512), kecerdasan emosional adalah kemampuan 
seseorang mengatur kehidupan emosinya dengan inteligensi (to manage our emotional life with intelligence); menjaga keselarasan emosi dan pengungkapannya (the appropriateness of emotion and its expression) melalui keterampilan kesadaran diri, pengendalian diri, motivasi diri, empati dan keterampilan sosial.

Dalam penelitian ini yang dimaksud dengan kecerdasan emosional adalah kemampuan siswa untuk mengenali emosi diri, mengelola emosi diri, memotivasi diri sendiri, mengenali emosi orang lain (empati) dan kemampuan untuk membina hubungan (kerjasama) dengan orang lain.

\section{Pengertian Belajar dan Hasil Belajar}

Manusia banyak mengalami perkembangan diberbagai bidang kehidupan. Perkembangan ini dimungkinkan karena adanya kemampuan untuk belajar, yaitu mengalami perubahan-perubahan mulai dari saat lahir sampai mencapai umur dewasa. Tentang belajar ini "Morgan dalam syaiful Sagala, mengemukakan bahwa belajar adalah setiap perubahan yang relatif menetap dalam tingkag laku yang terjadi sebagai suatu hasil dari latihan atau pengalaman ${ }^{2} \mathrm{Hal}$ senada juga disampaikan oleh Cronbach dalam Syaiful Bahri "Belajar sebagai suatu aktifitas yang ditunjukan oleh perubahan tingkah laku sebagai hasil dari pengalaman., "3elanjutnya menurut "Kingskey,yang dikutip oleh Syaiful Bahri bahwa Learning is the process by which behavior (in the broader sense) is originated or changed through practice or training. Belajar adalah suatu proses dimana tingkah laku (dalam arti luas) ditimbulkan atau diubah melalui latihan ataupun praktek"4. Sedangkan menurut Pasaribu bahwa Belajar diartikan sebagai suatu proses perubahan kegiatan, reaksi terhadap lingkungan. Perubahan

\footnotetext{
${ }^{2}$ Syaiful Sagala, Konsep dan Makna

Pembelajaran, (Bandung: cv Alfabeta, 2008), p.13

${ }^{3}$ Syaiful Bahri Djamarah. Psikologi Belajar

(Jakarta:Rineka Cipta, 2008), p.13

${ }^{4}$ Ibid. p. 13
}

kegiatan yang dimaksud mencakup pengetahuan, kecakapan, tingkah laku. Perubahan ini diperoleh melalui latihan (pengalaman) bukan perubahan yang dengan sendirinya karena pertumbuhan kematangan atau karena keadaan sementara seperti mabuk ${ }^{5}$.

Dari beberapa pendapat para ahli tentang pengertian belajar yang dikemukakan diatas dapat dipahami bahwa belajar merupakan perubahan pada diri orang yang belajar. Akan tetapi tidak semua perubahan yang terjadi pada seseorang merupakan hasil belajar. Peru-bahan yang disebabkan karena pertum-buhan dan kematangan bukan merupakan akibat belajar, tetapi terjadi karena dorong-an insting, sama halnya dengan perubahan yang terjadi akibat penyakit tidak dapat dikatakan sebagai hasil belajar, karena perubahan seperti itu diluar kemampuan seseorang.Perubahan yang terjadi karena belajar tidak timbul begitu saja, belajar lebih banyak menumbuhkan kegiatan yang disadari, suatu aktivitas psikhis dan latihan-latihan. Proses belajar terjadi karena adanya perangsang-perangsang dari luar diri individu, yang mengakibatkan perubahan dalam berbagai aspek kepribadian. Hal ini sejalan dengan pendapat Witherington dalam Ngalim Purwan-to" Belajar adalah suatu perubahan didalam kepribadian yang menyatakan diri sebagai pola baru dari pada reaksi yang berupa kecakapan, kebiasaan, sikap, pema-haman, pengertian."

Pendapat lain menjelaskan bahwa belajar adalah proses perubahan karena pengalaman, pola proses perubahan ini relatif menetap dalam aspek pemahaman, sikap, pengetahuan, kemampuan, keterampilan akibat pengalaman. Konsep belajar ini berbeda dengan yang sebelumnya. Pada konsep belajar ini dijelaskan bahwa perubahan tingkah laku yang diperoleh dari seseorang, oleh karena itu dapat

\footnotetext{
5 Posted: Juli 4, 2009 by techonly 13 in education 25

${ }^{6}$ M. Ngalim Purwanto, Psikologi Pendidikan

(Bandung: Remaja Rosdakarya, 2002), p 84
} 
dikatakan suatu perubahan tingkah laku dapat terjadi karena belajar, maka perubahan yang terjadi relatif menetap, artinya harus merupakan akhir dari pada suatu periode waktu yang cukup panjang. Berapa lama periode waktu berlangsung sulit ditentukan dengan pasti.Seperti diungkapkan oleh Winkel, "Perubahan akibat belajar itu akan bertahan lama, bahkan sampai taraf tertentu tidak menghilang lagi. Kemampuan yang diperoleh menjadi hak milik pribadi yang tidak akan hapus begitu saja.

Konsep ini menekankan bahwa perubahan yang terjadi pada diri seseorang yang belajar akan bertahan lama, selanjutnya para ahli biasanya merumuskan hasil belajar secara relatif, bersifat konstan dan membekas. Menurut Henry E. Garret dalam Syaiful Sagala "Belajar merupakan proses yang berlangsung dalam jangka waktu yang lama melalui latihan maupun pengalaman yang membawa kepada perubahan diri."

Berdasarkan pendapat-pendapat diatas maka disimpulkan bahwa belajar adalah proses perubahan dalam pengetahuan, pemahaman keterampilan dan sikap. Perubahan itu bersifat relatif konstan dan membekas akibat pengalaman. Untuk menentukan apakah pada diri seseorang telah terjadi proses belajar tidak mudah, sebab proses belajar bersifat internal, artinya proses tidak dapat dilihat dengan nyata, proses itu terjadi dalam diri seseorang yang sedang mengalami belajar.

Hasil belajar merupakan kemampuan yang dimiliki pembelajar, adalah mereka yang mengikuti suatu program yang meliputi kemampuan kognitif, afektif dan psikomotor. Lebih rinci lagi dapat dikatakan bahwa penguasaan terhadap kemampuan keterampilan intelektual, strategi kognitif, informasi verbal, kemampuan motorik, dan sikap. Hasil belajar merupakan hasil yang diperoleh siswa dalam belajarnya. "Gagne mengemukakan bahwa hasil belajar adalah

\footnotetext{
${ }^{7}$ Read more: http://tesisdisertasi.

Blogspot.comp/2010/03/pengertian belajar.html ${ }^{8}$ op cit, p. 84
}

hasil proses belajar mengajar yang dicapai pembelajar dalam menguasai materi yang telah diajarkan. ${ }^{9}$ Selanjutnya menurut “" Oemar Hamalik, Hasil belajar adalah bila seseorang telah belajar akan terjadi perubahan tingkah laku pada orang tersebut, misalnya dari tidak tahu menjadi tahu, dan dari tidak mengerti menjadi megerti. ${ }^{10}$

Berdasarkan beberapa pendapat diatas dapat dikatakan bahwa hasil belajar yang dimiliki siswa adalah hasil kemampuan siswa setelah mereka mengikuti program pembelajaran.

\section{Pengertian Belajar Kooperatif}

Cohen mendefinisikan belajar koope-ratif sebagai berikut "Cooperative learn-ing will be defined as student working together in a group small enough that everyone participate on a collective task that has been clearly assingn. Moreover, students are expected to carry out their task without direct and immediate supervision of the teacher". " Definisi ini mengandung arti bahwa belajar kooperatif menunjukan ciri sosiologis yaitu penekanannya pada aspek tugas-tugas kolektif yang harus dikerjakan bersama dalam kelompok dan pendelegasian wewenang dari guru kepada siswa. Guru berperan sebagai fasilitator dalam membimbing siswa menyelesaikan materi atau tugas.

Selanjutnya menurut Slavin bahwa belajar kooperatif ialah "Cooperative learning methods share the idea that student work together to learn and are responsible for their own". ${ }^{12}$ Artinya bahwa dalam belajar kooperatif siswa belajar bersama, saling menyumbang pemikiran dan bertanggung jawab terhadap pencapaian hasil belajar secara individu maupun kelompok.

Belajar secara kooperatif adalah belajar bersama dalam kelompok tetapi

\footnotetext{
${ }^{9}$ Ibid, $\mathrm{p} 42$

${ }^{10} \mathrm{http} /$ indramunawar. Blogspot. Comp/2009/06/ hasil belajar

${ }^{11}$ Nur Asma, model pembelajaran kooperatif (Jakarta: Depdiknas Dikti, 2006) p. 11

${ }^{12}$ Ibid, p 11
} 
berbeda dengan belajar kelompok yang selama ini dilaksanakan di sekolah. Menurut Eanes konsep belajar kooperatif adalah kerja sama anggota dalam kelompok untuk mencapai tujuan bersama.Sedangkan belajar kelompok yang dilaksanakan di sekolah adalah lebih menitik beratkan pada hasil kelompok $^{13}$.

Lungrend seperti yang dikutip oleh Nur Asma menyatakan bahwa belajar kooperatif dapat menciptakan situasi dimana keberhasilan individu ditentukan atau dipengaruhi oleh keberhasilan kelompok. ${ }^{14}$

Berdasarkan uraian di atas dapat di simpulkan beberapa karesteristik dari belajar kooperatif tersebut sebagai berikut: 1) kelas dibagi atas kelompok-kelompok kecil, dengan anggota kelompok yang terdiri dari beberapa orang siswa yang memiliki kemampuan akademik yang bervariasi serta memprhatikan jenis kelamin dan etnis; 2) siswa belajar dengan kelompoknya dengan bekerja sama untuk menguasai materi pelajaran dengan saling membantu; 3) sistem penghargaan lebih berorientasi kepada kelompok dari pada individu.

\section{B. HIPOTESIS TINDAKAN}

Berdasarkan acuan teori rancangan intervensi tindakan yang telah diuraikan sebelumnya maka rumusan hipotesis penelitian tindakan ini adalah model pembelajaran kooperatif Jigsaw diduga dapat meningkatkan hasil belajar IPS siswa sekolah dasar kelas III di SD Laboratorium Universitas Negeri Gorontalo yang berjumlah 20 orang.

\section{METODE PENELITIAN}

Penelitian ini menggunakan metode penelitian tindakan kelas (Classroom Research) yaitu bentuk khusus dari penelitian tindakan kelas (Action Research) yang dilakukan dikelas dalam bentuk

${ }^{13}$ Eanes. Content area literacy for today and tomorrow. Albany: ( Delmar Publisher, 1997. ) p. 132

${ }^{14}$ Nur Asma, op cit, p. 22 spiral $^{15}$. Bentuk penelitian tindakan dipilih atas dasar pemikiran bahwa guru SD adalah pelaksana pendidikan dikelas yang mampu mengidentifikasi permasalahan pembelajaran namun memiliki keterbatasan kemampuan dalam menyelesaikan masalah khususnya berkaitan dengan pembelajaran IPS, untuk itu peneliti bermaksud melakukan penelitian tindakan kelas dengan bekerja sama dengan guru kelas untuk meningkatkan hasil belajar IPS.

Desain penelitian yang digunakan adalah model dari Kemmis dan Mc Taggart berupa satu siklus atau putaran kegiatan yang meliputi tahap-tahap rancangan pada setiap putarannya yaitu 1). Perencanaan (planning), 2). Tindakan (acting), 3). Pengamatan (observing), 4. Refleksi (reflecting), dan akan diadakan revisi perencanaan pada siklus ulang jika masih diperlukan.

Subjek penelitian adalah siswa kelas III SD Laboratorium UNG yang berjumlah 20 orang. Pemilihan subjek penelitian berdasarkan observasi dan wawancara dengan guru bahwa pembelajaran IPS di SD ini masih didominasi oleh guru, siswa kurang memperoleh kesempatan untuk berinteraksi baik dengan guru maupun sesama siswa lainnya sehingga mempengaruhi hasil belajar IPS menjadi rendah.

\section{HASIL PENELITIAN DAN PEMBA- HASAN}

\section{A. Deskripsi Data Hasil Penelitian}

Dari hasil observasi terhadap implementasi tindakan pada siklus I, selama kegiatan pembelajaran berlangsung, peneliti dan kolaborator mengamati jalannya kegiatan untuk melihat apakah tindakan-tindakan tersebut sesuai dengan rencana, apakah setelah tindakan siswa telah dapat meningkatkan hasil belajar melalui cooperative learning sesuai dengan yang diharapkan.

\footnotetext{
${ }^{15}$ Arikunto, Suharsimi. Penelitian Tindakan Kelas. Bumi Aksara (Jakarta : 2007). P 105
} 
Tabel 4.1. Obsevasi penilaian hasil belajar IPS melalui Belajar Kooperatif siklus 1

\begin{tabular}{ccccccccc}
\hline & & \multicolumn{2}{c}{ Baik } & \multicolumn{2}{c}{ Cukup } & \multicolumn{2}{c}{ Kurang } & \multirow{2}{*}{ No. } \\
\cline { 3 - 7 } & Aspek & Frekuensi & \% & Frekuensi & \% & Frekuensi & \% & Rerata \\
\hline 1. & Kerjasama & 5 & 25 & 10 & 50 & 5 & 25 & 64,16 \\
2. & $\begin{array}{c}\text { Tanggung } \\
\text { Jawab }\end{array}$ & 6 & 30 & 4 & 20 & 10 & 50 & 62,50 \\
3. & $\begin{array}{c}\text { Kedisiplinan } \\
\text { Menghargai }\end{array}$ & 6 & 30 & 5 & 25 & 9 & 45 & 63,33 \\
4. & $\begin{array}{c}\text { pendapat orang } \\
\text { lain }\end{array}$ & 2 & 10 & 10 & 50 & 8 & 40 & 60 \\
5. & Kejujuran & 7 & 35 & 8 & 40 & 5 & 25 & 67,5 \\
\hline
\end{tabular}

\section{Hasil Observasi Siklus 1}

Bagian ini merupakan paparan tentang hasil pengamatan selama siklus pertama yang nantinya akan menjadi dasar perencanaan untuk penetapan revisi tindakan yang akan dilakukan pada siklus kedua.

Tabel di atas menunjukkan bahwa hasil belajar IPS untuk semua aspek pengamatan menunjukkan bahwa siswa yang memper-oleh nilai baik sebesar $26 \%$ dari 20 orang siswa, nilai cukup sebesar $37 \%$ dan nilai kurang sebesar $32 \%$. Hal ini belum menggambarkan target yang ingin dicapai sehingga perlu ditingkatkan lagi pada siklus kedua.

\section{B. Analisis dan Refleksi}

Berdasarkan pemantauan siklus pertama, peneliti dapat mengemukakan bahwa setelah diberi tindakan, yaitu pembelajaran IPS melalui cooperative learning, maka kemampuan siswa dalam menjawab soal-soal baik individu maupun kelompok meningkat bila dibandingkan dengan pencapaian hasil tes awal. Akan tetapi peningkatan itu belum berarti atau belum memuaskan peneliti karena masih jauh dari target yang ingin dicapai. Namun ada hal yang menggembirakan peneliti yaitu situasi pembelajaran didalam kelas dalam kurun waktu selama siklus pertama, berlangsung dengan baik. Hal ini terbukti dengan sikap antusiasme siswa saat mendengarkan penjelasan guru ataupun dalam kegiatan diskusi kelompok, siswa tekun dalam mengerjakan tugas dan selalu menaati aturan main dalam diskusi.

Dari hasil pengamatan terhadap diskusi kelompok, diperoleh hasil bahwa kemampuan siswa dalam melakukan kerjasama dan kemampuan menghargai pendapat orang lain masih kurang yakni tampak dalam hal kemampuan membagi ide dan pengetahuannya untuk membantu orang lain kemampuan menanggapi kritik orang lain dengan penuh persahabatan serta kemampuan saling memberi dan menerima.

Untuk itu kemampuan tersebut akan diperbaiki pada siklus kedua.

Masih kurangnya kemampuan anak dalam aspek kerjasama dan menghargai pendapat orang lain pada siklus pertama ini karena beberapa kekurangan yang terjadi dalam kegiatan pembelajaran antara lain : 1) kurangnya penjelasan guru tentang hal-hal yang harus diperhatikan sehubungan dengan cooperative learning dalam kegi-atan diskusi kelompok; 2) kurangnya bim-bingan guru pada setiap kesulitan yang dialami siswa dalam diskusi kelompok; 3) perhatian guru tidak merata sehingga siswa yang kurang responsif terabaikan; 4) kegiatan tanya jawab kurang intensif karena keterbatasan waktu. 
Berdasarkan hasil pantauan peneliti selama melakukan tindakan pada siklus pertama, peneliti berpendapat bahwa perlu ditingkatkan upaya agar siswa lebih dilibatkan lagi dalam interaksi belajar, sehingga tidak hanya beberapa siawa saja yang meningkat kemampuannya dalam memahami setiap aspek yang ada dalam cooperative learning karena hal ini akan berdampak pula pada peningkatan hasil belajar siswa khususnya pada mata palajaran IPS.

Untuk itu, maka peneliti memutuskan untuk melanjutkan tindakan yang dapat meningkatkan keaktifan siswa dan kemampuan memahami setiap aspek cooperative learning pada siklus 2

\section{C.Tahap Pelaksanaan Tindakan}

Pertemuan pada siklus kedua ini dilaksanakan pada hari senin tanggal 24 mei 2010. Kegiatan pembelajaran dimulai pada pukul 09.00 wita dan berakhir pada pukul 10.00 wita yang terdiri dari kegiatan awal, kegiatan inti dan kegiatan akhir.

Pembelajaran pada siklus dua ini diharapkan agar siswa dapat : 1) Menjelaskan manfaat siskamling, 2) menjelaskan manfaat hidup rukun bertetangga, 3 ) menjelaskan pentingnya persatuan, 4) menyebutkan contoh kerja sama di lingkungan rumah.

\section{a). Kegiatan awal}

Pada kegiatan awal ini seperti bisanya yang pertama dilakukan guru adalah mengkondisikan kelas, kemudian dilanjutkan dengan berdoa dan mengucapkan salam. Selanjutnya guru menyampaikan kompetensi dasar serta tujuan pambelajaran yang harus dicapai siswa.

Siswa didorong untuk mengungkapkan pengetahuan awal tentang konsep yang akan dipelajari dengan cara memancing pertanyaan berupa pertanyaan problematik tentang fenomena yang sering ditemui siswa sehari-hari dan guru mengaitkannya dengan konsep yang akan dipelajari.

Guru memberi pertanyaan; siapa dirumah yang suka membantu Ibu mencuci piring atau membantu Ayah menyapu di halaman rumah. Ada siswa yang spontan menjawab bahwa dia sudah biasa melakukan itu. Berdasarkan komentar siswa tersebut, guru mendekatinya dengan mengajukan beberapa pertanyaan sehubungan dengan materi yang akan dibahas. Cara ini dilakukan karena sangat membantu anak untuk aktif termasuk yang biasanya pasif atau diam saja.

\section{b). Kegiatan Inti}

Guru menjelaskan secara singkat materi yang akan dibahas pada hari ini, kemudian dilanjutkan dengan kegiatan tanya jawab tentang hal-hal yang belum dipahami.

Pembelajaran IPS pada hari ini dengan memfokuskan pada: 1) Peningkatan kemampuan untuk bekerja sama; siswa dapat membagi ide dan pengetahuannya untuk membantu setiap anggota kelompoknya, 2) Disiplin yakni siswa dapat menye-lesaikan tugas secara tepat waktu, 3) Kemampuan menghargai pendapat orang lain; siswa menanggapi dengan penuh persahabatan kritik, ide, pendapat orang lain serta saling mengakui kekurangan dan kelebihan orang lain.

Selanjutnya secara heterogen siswa dibentuk dalam 4 kelompok masingmasing terdiri 5 orang perkelompok. Guru menginformasikan tugas-tugas yang dikerjakan dalam kelompok serta menunjuk salah satu siswa yang menjadi ahli informasi dari masing-masing kelompok untuk belajar bersama dan merencanakan cara memberikan informasi kekelompok semula.

Guru membagikan materi dan LKS kepada masing-masing anggota dalam kelompok dan selanjutnya menugasi siswa untuk mengadakan diskusi dalam kelompok. Dalam kegiatan diskusi kelompok guru membimbing siswa dengan menambahkan informasi dan memberi penguatan untuk membangun interaksi siswa yang dapat membangkitkan keberanian dan keterampilan siswa agar seluruh siswa benar-benar dilibatkan dalam proses pembelajaran. Diskusi kelompok berlangsung 30 menit. 
Tabel 4.2. Observasi Penilaian Hasil Belajar IPS Melalui Cooperative Learning Siklus 2

\begin{tabular}{|c|c|c|c|c|c|c|c|c|}
\hline \multirow{2}{*}{ No. } & \multirow{2}{*}{ Aspek } & \multicolumn{2}{|l|}{ Baik } & \multicolumn{2}{|c|}{ Cukup } & \multicolumn{2}{|c|}{ Kurang } & \multirow{2}{*}{ Rerata } \\
\hline & & Frekuensi & $\%$ & Frekuensi & $\%$ & Frekuensi & $\%$ & \\
\hline 1. & Kerjasama & 16 & 25 & 4 & 50 & - & - & 79,99 \\
\hline 2. & $\begin{array}{l}\text { Tanggung } \\
\text { Jawab }\end{array}$ & 16 & 30 & 4 & 20 & - & - & 79,99 \\
\hline 3. & Kedisiplinan & 17 & 30 & 1 & 25 & - & - & 80,33 \\
\hline 4. & $\begin{array}{l}\text { Menghargai } \\
\text { pendapat orang } \\
\text { lain }\end{array}$ & 17 & 10 & 1 & 50 & - & - & 80,33 \\
\hline 5. & Kejujuran & 18 & 35 & 2 & 40 & - & - & 81,56 \\
\hline
\end{tabular}

Berdasarkan hasil pengamatan dapat disimpulkan bahwa kemampuan siswa dalam menyampaikan ide dan pendapat, saling mengakui kekurangan dan kelebihan orang lain serta kemampuan menyelesaikan tugas secara tepat waktu sudah meningkat bila dibandingkan dengan siklus pertama. Hal ini dapat diamati langsung dalam kegiatan diskusi kelompok. Penya-jian laporan berlangsung hangat karena masing-masing kelompok berusaha mena-nggapi laporan kelompok lain. Siswa memberi tepuk tangan ketika wakil kelompok selesai menyajikan laporannya atau pada saat wakil kelompok menjawab pertanyaan kelompok lain.

Untuk masing-masing kelompok, siswa yang bertugas sebagai ketua, penulis dan pelapor dipilih oleh siswa sendiri. Dalam hal ini ada ketua yang merangkap sebagai penulis dan pelapor. Setelah penyajian laporan masing-masing kelompok selesai, guru meberikan pujian kepada masing-masing kelompok yang terlah bekerja dengan aktif dalam menyelesaikan tugas kelompok. Guru juga mengatakan bahwa penyajian laporan sudah berjalan dengan baik, karena masing-masing kelompok telah aktif untuk menanggapi laporan kelompok lain.

\section{c). Kegiatan Akhir}

Pada kegiatan akhir ini guru membimbing siswa secara bersama-sama menyimpulkan materi yang dibahas tentang kerja sama di lingkungan rumah, sekolah dan kelurahan. Serta menganjurkan kepada siswa untuk mempelajari kembali materi tersebut dirumah dan diharapkan agar supaya melaksanakan dalam kehidupan sehari-hari. Sebagai penutup guru melakukan evaluasi secara lisan.

\section{Observasi siklus 2}

Kegiatan pembelajaran pada siklus 2 bertujuan untuk memperbaiki kemampuan yang masih kurang pada pelaksanaan siklus satu. Dari hasil pengamatan langsung pada proses pembelajaran melalui belajar kooperatif Jigsaw, telah terjadi peningkatan hasil belajar siswa dalam hal kemampuan untuk bekerja sama, disiplin dalam mengerjakan tugas dan kemampuan menghargai pendapat orang lain.

Data yang terkumpul pada siklus 2 adalah sebagai berikut:

\section{1). Hasil observasi siklus 2}

Tabel di atas menunjukkan bahwa hasil belajar IPS untuk semua aspek pengamatan menunjukkan bahwa siswa yang memperoleh nilai baik sebesar $85 \%$ dari 20 orang siswa, nilai cukup sebesar $15 \%$ dan nilai kurang sebesar $0 \%$. Hal ini 
menggambarkan target telah tercapai yakni lebih dari $80 \%$ siswa telah berhasil memperoleh nilai baik.

\section{Analisis dan Refleksi siklus 2}

Berdasarkan pemantauan dan hasil observasi pada siklus kedua ini, peneliti dapat mengemukakan bahwa setelah diberi tindakan, yaitu pembelajaran IPS dengan melalui cooperative learning maka hasil belajar siswa meningkat, hal ini dapat diamati secara langsung pada siklus kedua antara lain, 1. Aspek kerja sama; siswa sudah bisa membagi ide dan pengetahuannya untuk membantu setiap anggota dalam kelompoknya, 2. Aspek tanggung jawab; siswa telah mandiri dalam melengkapi tugas yang diberikan guru, 3 . Aspek kedisiplinan; siswa sudah bisa menyelesaikan tugas secara tepat waktu, 4 . Aspek menghargai pendapat orang lain; siswa sudah bisa menanggapi dengan penuh persahabatan kritik, ide dan pendapat orang lain, 5. Aspek kejujuran; siswa sudah dapat saling mengakui kelebihan dan kekurangan orang lain.

Peningkatan kemampuan ini dapat terjadi karena perbaikan dalam proses pembelajaran antara lain: 1). Memberi kesempatan penuh kepada siswa untuk saling merespon pertanyaan dari kelompok lain, 2). Menaati aturan main dalam diskusi, 3). Memberi penghargaan berupa pujian kepada siswa atau kelompok yang telah memperlihatkan kerja keras dan semangatnya dalam berdiskusi.

Strategi pembelajaran melalui cooperative learning (belajar kooperatif) Jigsaw ternyata efektif dalam memupuk kerjasama serta keberanian siswa dalam mengemukakan pendapat dan berbicara didepan umum sehingga telah terjadi peningkatan hasil belajar siswa dalam pembelajaran IPS kelas III sekolah dasar laboratorium Universitas Negeri Gorontalo.

Berikut ini akan diuraikan perbandingan hasil intervensi tindakan siklus 1 dan siklus 2 .

Tabel 4.3. Perbandingan Hasil Intervensi Siklus 1 dan siklus 2

\section{SIKLUS 1}

Hasil Observasi
Terhadap Hasil
Belajar IPS
Siswa:

a. $25 \%$ siswa mendapat nilai baik untuk aspek kerjasama

b. $30 \%$ siswa mendapat nilai baik untuk aspek tanggung jawab

c. $30 \%$ anak mendapat nilai baik untuk aspek kedisiplinan

d. $10 \%$ siswa mendapat nilai baik untuk aspek menghargai pendapat orang lain

e. $35 \%$ siswa mendapat nilai baik untuk aspek kejujuran

f. Rerata kumulatif untuk semua aspek kemampuan masih dibawah 85\% (belum mencapai target)

\section{SIKLUS 2}

\section{Hasil observasi Terhadap Hasil} Belajar IPS Siswa:

a. $80 \%$ siswa mendapat nilai baik untuk aspek kerjasama

b. $80 \%$ siswa mendapat nilai baik untuk aspek tanggung jawab

c. $85 \%$ siswa mendapat nilai baik untuk aspek kedisiplinan

d. $85 \%$ siswa mendapat nilai baik untuk aspek menghargai pendapat orang lain

e. $90 \%$ siswa mendapat nilai baik untuk aspek kejujuran

f. Rerata kumulatif untuk semua aspek kemampuan mencapai $85 \%$ (target tercapai) 


\begin{tabular}{cl}
\hline Hasil Observasi & Hasil Observasi \\
Terhadap Proses & Terhadap Proses \\
Pembelajaran : & Pembelajaran \\
a. Guru cukup baik & a. Guru lebih baik \\
merencanakan & lagi \\
pembelajaran & merencanakan \\
yang dimulai & pembelajaran \\
dengan & yang dimulai \\
menentukan & dengan \\
tujuan, & menentukan \\
menyiapkan & tujuan, \\
alat dan media & menyiapkan alat \\
pembelajaran & dan media \\
b. Guru cukup baik & pembelajaran \\
dalam & b. Guru sudah lebih \\
melaksanakan & baik lagi dalam \\
pembelajaran & melaksanakan \\
namun masih & pembelajaran \\
mendominasi & terbukti dengan \\
kegiatan dan & melibatkan anak \\
anak pasif & lebih aktif dalam \\
mendengarkan & proses belajar di \\
c. Guru cukup baik & kelas \\
dalam & c. Guru sudah lebih \\
melaksanakan & baik lagi dalam \\
evaluasi & melakukakan \\
pembelajaran, & evaluasi. \\
tanya jawab & Memberi \\
dengan anak & kesempatan \\
lebih terfokus & kepada anak \\
kepada anak & melakukan \\
yang aktif saja & kegiatan diskusi \\
sedang anak & dengan \\
yang pasif & berkelompok \\
kadang & untuk memupuk \\
terabaikan & keberanian anak \\
d. Minat dan & dalam \\
perhatian anak & mengemukakan \\
terhadap & pendapatnya \\
kegiatan & d. Minat dan \\
pembelajaran & perhatian anak \\
mudah beralih & sudah lebih baik \\
ke hal lain & lagi dengan \\
aktif bertanya & melibatkan \\
apabila & mereka secara \\
terdapat kata- & fisik dan \\
emosional dalam \\
\hline & kegiatan \\
pemangan & eembelajaran \\
e. Anak lebih aktif \\
\hline
\end{tabular}

\begin{tabular}{cl}
\hline \multicolumn{1}{c}{ dengan wacana } & lagi dalam \\
yang & bertanya apabila \\
dibahasnya & terdapat kata- \\
f. Anak terlibat & kata yang sulit \\
cukup aktif & dipahami anak \\
dalam & sehubungan \\
menggunakan & dengan wacana \\
media & Bahkan bisa \\
pembelajaran & mengomentari \\
& wacana yang \\
& sedang \\
& dipelajarinya \\
& f. Anak lebih \\
& antusiasme \\
& dalam \\
& menggunakan \\
& media \\
& pembelajaran \\
\hline
\end{tabular}

\section{B. Analisa Data}

Berikut ini hasil tes awal dan tes akhir hasil belajar IPS siswa kelas III sekolah dasar laboratorium Universitas Negeri Gorontalo.

Tabel 10. Data Hasil Tes Awal dan Tes Akhir Hasil Belajar IPS

\begin{tabular}{cccc}
\hline No. & Responden & $\begin{array}{c}\text { Tes } \\
\text { Awal }\end{array}$ & $\begin{array}{c}\text { Tes } \\
\text { Akhir }\end{array}$ \\
\hline 1. & 1 & 8 & 16 \\
2. & 2 & 6 & 15 \\
3. & 3 & 6 & 16 \\
4. & 4 & 5 & 13 \\
5. & 5 & 6 & 13 \\
6. & 6 & 6 & 15 \\
7. & 7 & 8 & 15 \\
8. & 8 & 7 & 15 \\
9. & 9 & 8 & 17 \\
10. & 10 & 8 & 17 \\
11. & 11 & 9 & 18 \\
12. & 12 & 8 & 18 \\
13. & 13 & 7 & 16 \\
14. & 14 & 8 & 17 \\
15. & 15 & 7 & 16 \\
16. & 16 & 7 & 16 \\
17. & 17 & 9 & 17 \\
18. & 18 & 10 & 19 \\
19. & 19 & 8 & 17 \\
\hline
\end{tabular}




\begin{tabular}{llll}
\hline 20. & 20 & 8 & 18 \\
\hline
\end{tabular}

Tabel di atas menunjukkan bahwa pada tes awal skor terendah 5 dan skor tertinggi 10 . Sedangkan pada tes akhir, skor terendah 13 dan skor tertinggi 19.

Grafik 1. menunjukkan bahwa telah terjadi peningkatan terhadap hasil belajar IPS setelah diberi tindakan dari 7,45 $(37,25 \%)$ menjadi $16,2(81 \%)$. Jadi telah terjadi peningkatan sebesar $43,75 \%$.

Dengan demikian target telah tercapai yaitu peningkatan rerata $85 \%$ dari skor maximal. Dari hasil pemgamatan terhadap proses pembelajaran IPS melalui Belajar Kooperatif diperoleh hasil bahwa kemampuan siswa pada aspek kerjasama, tanggung jawab, kedisiplinan, menghargai pendapat orang lain dan kejujuran mengalami peningkatan pada siklus kedua. Hal ini tampak pada meningkatnya Jumlah siswa yang memperoleh nilai baik diatas $85 \%$ lebih dari total jumlah anak ( 20 orang ). Ini disebabkan karena perbaikan pada siklus kedua.

\section{Pembahasan hasil penelitian}

Kegiatan pembelajaran IPS siswa melalui belajar kooperatif model jigsaw selama dua siklus telah terbukti dapat meningkatkan hasil belajar siswa. Peningkatan telah terjadi karena pembelajaran melalui belajar kooperatif dapat melatih siswa untuk lebih memahami kedudukannya sebagai makhluk sosial yakni bagaimana membina hubungan yang baik dan hidup bersama secara tertib dan teratur dengan orang lain, berani mengambil resiko, bertanggung jawab serta selalu menghargai hak-hak orang lain.

Belajar kooperatif mempunyai ide bahwa siswa bekerjasama untuk belajar bertanggung jawab pada kemajuan temantemannya. Hal senada juga dikemukakan oleh Vygotsky, menurutnya bahwa aktivitas kolaboratif yang ada pada anak-anak akan mendukung pertumbuhan mereka, karena anak-anak seusia lebih senang bekerja dengan orang yang satu zone zpd dengan yang lain. Pemodelan dalam perilaku kelompok kolaboratif lebih maju dari pada penampilan mereka sebagai individu. $^{16}$ Menurutnya siswa sebaiknya belajar melalui interaksi dengan orang dewasa dan teman sebaya yang lebih mampu. Interaksi sosial ini memacu terbentuknya ide baru dan memperkaya pengembangan intelektual siswa.

Meskipun penggunaan model belajar kooperatif dapat meningkatkan hasil bela-

Responden

Grafik 1. Data Tes Awal dan Tes Akhir

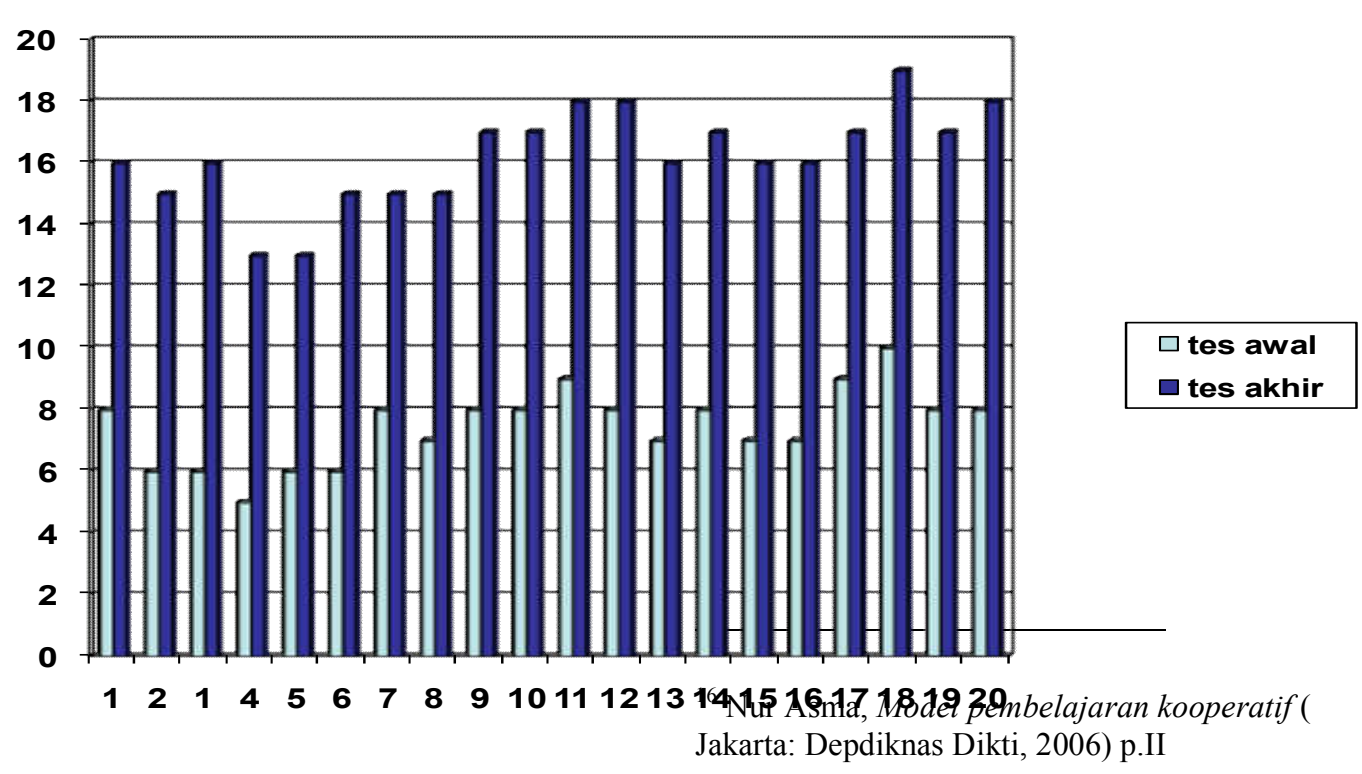


jar siswa, namun satu hal yang harus dihadapi guru dimana sebagian besar anak kurang tertarik dengan pelajaran IPS karena materinya terlalu banyak mengandung konsep-konsep abstrak. Perhatian mereka mudah beralih ketempat lain. Maka dalam penerapan lebih lanjut pada proses pembelajaran, kegiatan ini membutuhkan persiapan yang matang.

Untuk itu, dalam penerapan model belajar kooperatif dalam meningkatkan hasil belajar siswa maka dipenuhi hal-hal sebagai berkut agar diperoleh hasil yang optimal, antara lain; 1) Mengaktifkan anak dalam kegiatan pembelajaran, misalnya memberikan sejumlah pertanyaan yang dapat direspon langsung, 2) Membangkitkan rasa percaya diri agar anak mempunyai keberanian untuk berbicara didepan umum, 3) Memberikan penghargaan berupa pujian kepada siswa atau kelompok yang telah memperlihatkan kerja keras dan semangat dalam berdiskusi, 4) Melatih anak untuk dapat memupuk kerjasama dan saling memberikan penghargaan.

Berdasarkan analisa data dan temuan penelitian, Pembelajaran dengan menerapkan Model Belajar Kooperatif dapat meningkatkan hasil belajar siswa khususnya hasil belajar IPS kelas III sekolah dasar laboratorium Universitas Negeri Gorontalo.

\section{SIMPULAN， IMPLIKASI DAN SA- RAN}

\section{A. Kesimpulan}

Berdasarkan pengamatan selama dua siklus dan pembahasan hasil penelitian tindakan, dapat dikemukakan beberapa kesimpulan sebagai berikut:

1. Proses pembelajaran melalui kegiatan belajar kooperatif dapat meningkatkan hasil belajar IPS siswa terdiri dari:
(a) Menyampaian tujuan pembelajaran dan pokok materi kepada siswa
(b) Membentuk kelompok secara hete- rogen

(c) Menyajikan informasi kepada siswa terhadap posisi dan tempat selama kegiatan pembelajaran

(d) Menyiapkan alat, bahan dan media yang diperlukan dalam pembelajaran

(e) Mengaktifkan siswa dalam pembelajaran sehingga dapat memancing interaksi siswa baik dengan guru maupun dengan sesama siswa lainnya

(f) Memberikan penghargaan

2. Hasil observasi terhadap hasil belajar IPS siswa setelah diadakan tindakan menunjukkan peningkatan jumlah anak yang mendapat nilai baik (85\%) sebesar lebih dari $80 \%$ jumlah siswa.

3. Hasil belajar IPS meningkat secara signifikan setelah peneliti menerapkan strategi belajar kooperatif dalam proses pembelajaran. Hal ini dibuktikan dengan meningkatnya kemampuan siswa dalam menerapkan detiap aspek yang ada strategi belajar kooperatif.

\section{B. Saran}

Setelah melakukan penelitian ini, peneliti mendapatkan banyak manfaat, terutama dalam mengembangkan profesi baik sebagai pengajar maupun peneliti. Oleh sebab itu, peneliti ingin membagi pengalamnnya dengan memberikan beberapa saran kepada pihak-pihak berikut ini:

1. Peneliti lain, kiranya dapat melakukan penelitian tindakan dengan fokus serupa namun kontennya berbeda. Peneliti menginginkan peneliti lainnya akan meneliti penelitian tindakan kelas benar-benar tekun dengan konteks permasalahandalam bidang pekerjaan mereka

2. Guru perlu mempertimbangkan untuk mengorganisir pengaturan kelas agar siswa mudah bekerja dalam kelompok atau secara berpasangan. Dalam hal ini guru guru dapat menjadi seorang fasilitator ketimbang sebagai diktator bagi siswanya. Guru perlu 
mencoba dan berusaha memahami para siswa secara individu.

3. Para siswa dengan secara aktif dalam pembelajaran sehingga proses perbaikan pembelajaran yang dilakukan oleh guru dapat berlangsung dengan baik karena mendapatkan dukungan yang positif dari para siswa. Perbaikan pembelajaran yang dilakukan oleh guru tidak akan berhasil apabila siswa tidak memberikan dukungan positif dalam pembelajaran.

4. Kepala sekolah agar dapat memberikan dukungan dan kesempatan kepada para guru untuk melakukan berbagai kreasi dan inovasi pembelajaran sehingga para guru lebih leluasa dalam hal mengikuti berbagai kegiatan peningkatan kualitas pembelajaran seperti diklat-diklat dan memberikan dukungan dana yang secara langsung dapat membantu guru dalam mengikuti kegiatan dimaksud.

5. Para stakeholder pendidikan kiranya dapat memberikan dukungan berupa pandangan-pandangan positif terhadap kegiatan-kegiatan guru dalam mengembangkan pembelajaran di kelas. Bahwa pengalaman-pengalaman pembelajaran pada waktu-waktu yang lalu dapat dilakukan perbaikan-perbaikan pada saat sekarang berdasarkan kebutuhan dan permasalahan siswa, sehingga ada hal-hal baru yang muncul dalam aktivitas/proses pembelajaran yang mungkin berbeda dengan proses pembelajaran yang lalu.
6. Orang tua siswa hendaknya secara aktif peduli terhadap berbagai kebutuhan anaknya (siswa) terutama terhadap berbagai kebutuhan pembelajaran sehingga siswa dapat belajar sebagai-mana mestinya.

\section{DAFTAR PUSTAKA}

Arikunto, Suharsimi. Penelitian Tindakan Kelas. Bumi Aksara (Jakarta : 2007). P 105

Depdiknas,Kurikulum Pendidikan Dasar Tahun 2006, h,621.

Eanes. Content area literacy for today and tomorrow. Albany: ( Delmar Publisher, 1997. ) p.132

http/ indramunawar. Blogspot. Comp/2009/06/ hasil belajar

M. Ngalim Purwanto, Psikologi Pendidikan (Bandung: Remaja Rosdakarya, 2002), p 84

Nur Asma, Model pembelajaran kooperatif ( Jakarta: Depdiknas Dikti, 2006) p.II

Nur Asma, model pembelajaran kooperatif (Jakarta: Depdiknas Dikti, 2006) p. 11

Posted: Juli 4, 2009 by techonly 13 in education 25

Read more: http://tesisdisertasi.

Blogspot.comp/2010/03/pengertian

belajar.html 